Proceedings of the 2019 International Scientific Conference 'Economic Sciences for Agribusiness and Rural Economy' No 3, Warsaw, 5-7 June 2019, pp. 112-117

\title{
ADAPTATION PROCESSES OF THE AGRARIAN SECTOR FOR REALIZATION OF THE EXISTING POTENTIAL
}

\author{
Petro Putsenteilo, PhD, Associate Professor ${ }^{1 *}$; Yuriy Klapkiv, DSc, Assistant \\ Professor $^{2^{* *}}$; Viktoriia Vovk, DSc, Assistant Professor ${ }^{3^{* * *}}$
}

\author{
${ }^{1}$ Faculty of Agricultural Economics and Management, Ternopil National Economic University \\ ${ }^{2}$ Faculty of Economics and Sociology, University of Lodz \\ ${ }^{3}$ Institute of Economics and Management, National University of Water and Environmental Engineering \\ ${ }^{*}$ https://orcid.org/0000-0003-0168-9316 \\ ** https://orcid.org/0000-0002-9771-5357 \\ *** https://orcid.org/0000-0002-8187-4257
}

\begin{abstract}
The agrarian sector of Ukraine with its basic component of agriculture is increasingly becoming the systemforming factor in the national economy. It creates the factors for maintaining the sovereignty of the state: food and, within certain limits, the economic and ecological, energy security of the state, ensures the development of technologically related branches of the national economy. The main aim of the study was to compare the diversity of agrarian structure and land productivity in Ukraine. The basic commodity positions of agrarian products and the existing potential for development are determined. The measures necessary for the development of the agrarian sector of Ukraine, the expansion of markets and the successful promotion of agrarian products to the world food markets are singled out.
\end{abstract}

Key words: agricultural sector, adaptation processes, agricultural insurance, global agri-food system, potential JEL codes: Q13, Q18

\section{INTRODUCTION}

One of the most important aspects of the potential competitiveness of agriculture is the competitiveness of its resources and the study of potential opportunities allows us to determine the direction in the agricultural sector development strategy not only of this state but also of the whole region. The agrarian sector has its own specific features in the context of the natural, climatic, territorial, financial, material and production and national conditions of the country's development. Agrarian production in the territory of modern Ukraine is a traditional field of activity and is primarily due to the nature of the relationships of people in economic life, the type of tools and the direction of development of natural resources.

The effective development of the agrarian sector can be achieved at the organizational, economic, technological and financial and investment symbiosis of

\footnotetext{
${ }^{1}$ Corresponding author: p.putsenteilo@tneu.edu.ua

${ }^{2}$ Corresponding author: jurij.klapkiv@uni.lodz.pl

${ }^{3}$ Corresponding author: v.m.vovk@nuwm.edu.ua
} 
all units, since the basis of added value is formed at the expense of agricultural raw materials and products that are being processed for other industries. In Ukraine, the agrarian sector, in the current circumstances, is becoming a decisive component of the state's economy and plays an extremely important role in ensuring its economic and social stability. The agrarian sector needs careful attention to improving the development efficiency both in the short and long term of its development, as it is a socially important industry that produces food resources and provides food security.

\section{THEORETICAL BASICS}

The agrarian sector is a special industry in the system of the national integral economy of Ukraine, because its development has a decisive influence on the standard of living of the people. The achieved level of competitiveness of the agrarian sector, as well as the prospects for its development in the conditions of global competition directly affect the living standards of the population, the cost of the consumer basket, the conditions and quality of reproduction of the labour force in the national economy. It is the agrarian sector that serves as an indicator of the general state of the economy, it has a leading place in addressing food issues, and the development and stability of the agrarian sector determine the normal functioning of the whole economy of the state and the welfare of its population. Today, the Ukrainian agrarian sector has a production potential that far exceeds the needs of the domestic market. It is a link that, on the one hand, can become the engine of the development of the national economy and its effective integration into the world economic space, and on the other hand, to contribute to the growth of incomes of the rural population, which accounts for more than one third of the entire population of the country.

\section{MATERIALS AND METHODS}

The data used for documenting the paper was collected mainly through desk research. Different information sources from European and national level, such as reports, country fact sheets and articles were consulted.
The work included an analysis of available Ukrainian and foreign scientific literature on the development of agrarian business and export of products. The criterion for choosing a literature for consideration was the current and potential impact of the dynamics of agricultural production and exports, taking into account the activity of agricultural enterprises and households (small businesses). The main aim of the study was to compare the diversity of agrarian structure and land productivity in Ukraine. The analyzed changes in the agrarian structure concern, among other things, the structure of the number of farms and the structure of production in farms. The main export commodity positions of agrarian products are determined.

\section{RESULTS AND DISCUSSIONS}

The agrarian sector occupies a special place in the structure of the national economy. The state of the agrarian sector largely determines the national economic potential, economic and political situation in the country (Friedmann, 1980). From its development, the material and social well-being of the population depend on its supply of food, the supply of raw materials of processing industries and the provision of national food security of the country, because the level of consumption of the final product of the industry affects the very existence of man, his health and productivity (Georgescu-Roegen, 1960; Bernstein, 1994). Agriculture is the core of the agrarian sector, which produces agricultural raw materials for further processing and receipt of food products and is a determining factor in the final consumption.

Agriculture is based on inter-branch production cooperation, which connects it with industries that produce means of production, process and bring food to the consumer. Agricultural production also performs a social function, providing employment for the population, creating preconditions for raising the level and quality of life in the countryside. Thus, Timmer notes that agriculture is a special sector of the national economy in which land (soil) is an important factor in productive production as the part of the production function (Timmer, 1986). The priority of attention to the agrarian sector is determined 
by the indispensability of agricultural products and foodstuffs in the life of man and society, its exclusive social significance (Carter and Barham, 1996).

The agrarian sector of Ukraine with its basic component of agriculture is increasingly becoming the system-forming factor in the national economy. It creates the factors for maintaining the sovereignty of the state: food and, within certain limits, the economic and ecological, energy security of the state, ensures the development of technologically related branches of the national economy, forms the market for food products (Putsenteilo, Klapkiv and Kostetskyi, 2018).

Agricultural production serves as the core of the complex sector of the agrarian sector. This feature imposes the need for balance and proportionality between component parts (Musgrave, 1978). Consequently, the contradictions that arise and are solved in agriculture are an internal impulse for the development of the sector itself, which results in equalization of the development vectors of all branches. The main controversy is between fund-producing and consuming industries, agriculture and the industries for the processing, transportation and marketing of products (Wright and Kunreuther, 1975).

The agrarian sector of the economy is a set of industries that produce process and store and bring to the final consumer products produced from agricultural raw materials (Tomich, Kilby and Johnston, 1995). The agrarian sector of the economy includes those types of production, the functioning and development of which are subject to the creation of food. The existence of this set of industries and industries without a systemic connection is not efficient enough. Therefore, in order for the agrarian sector of the economy to fulfil its functions, it must have a certain structure (Jones and Woolf, 2006). The development of the agrarian sector is a dynamic process, each stage of which sets new tasks and needs new ways of solving them. The agrarian sector of Ukraine's economy enters into a new phase in its development - entry into the global space (Putsenteilo, 2011).

The globalization of the economy, including its agrarian sphere, is an objective reality, an inevitable process in the modern world. At the same time, this multi-dimensional and ambiguous process, which causes some controversy, promotes some of the destabilizing factors to affect the development of the agrarian sector, especially in the context of a weak national economy and ineffective government activity (Akram-Lodhi, 2007). That is why, at this stage, one of the most important areas of economic research is the study of trends and perspectives of the agrarian sector development in the context of intensifying globalization processes (Hymer and Resnick, 1969; Razavi, 2009).

One of the most important engines of transformation of the global agri-food system - and therefore of agrarian livelihoods - relates to the financial sector's recent rise in power and prominence. In the early 1970s, a suite of inter-related developments referred to generally as "financialization" initiated sweeping changes across the global economic landscape. These changes have provided powerful new mechanisms of accumulation, and they intersect in numerous ways with the current wave of land and resource dispossession (McMichael, 2012; Russi, 2013).

The development of agrarian production from a theoretical and methodological point of view is a complex process, agreed, firstly, with the decisive trends in the development of the national economy as a macro-economy, and secondly, with the requirements of adherence to the principles of a systematic approach to the formation of preconditions and factors of development, thirdly, with the requirements of the innovation and investment model of development of the industry, and fourthly, with the needs of sustainable development of rural areas, which provide for agro-industrial production, fifth, with the requirements of national security, including food safety standards, sixth, with the requirements of standardizing production and management systems based on current international standards and norms (Putsenteilo, Klapkiv and Kostetskyi, 2018).

In the broadest sense, the agrarian sector of the economy covers all enterprises of Ukraine irrespective of the form of ownership and organizational and legal form, which produce agricultural products and products of its primary processing, and associated service enterprises, as well as organizations (institutions) that develop and implementation of the state agricultural policy. In the narrow sense, it is 
considered only as a sector of the economy, covering all enterprises that produce agricultural products, carry out their primary processing and serve the specified processes.

Consequently, the agrarian sector is a complex diversified set of economically interconnected production and technological division of labour of agricultural sectors specializing in the production of agricultural products, their industrial processing, storage and sale, which also covers information and scientific support systems and is characterized by deep differences and specifics of individual elements, which requires the construction of an individual organizational, economic, and technological and technological policy regarding all business entities.

According to the most general signs the organizational structure of agriculture in Ukraine is outwardly similar to that of agricultural countries in Europe. It is also possible to identify certain phenomena and processes similar to those which have taken place in the countries of the European Union: concentration and specialization of production; technical and technological re-equipment of separate industrial structures, accompanied by a decrease in the number of employees; vertical integration in the agro-food sector, etc. (Byres, 1991). However, unlike the EU countries, different types of industrial formations develop not as harmonized parts of the single complex in Ukraine, but rather differentiated, often on an antagonistic basis. A system of organizational and economic mechanisms that can provide the functioning of the agrarian sector as a whole organism, which, firstly, develops on a steady basis (with the expanded reproduction of the human, natural resources, physical, financial and other capital involved in it), and secondly, fully fulfills its tasks and functions in the process of public reproduction is not yet formed.

The central concept for analysis of agrarian social relations is the form of production. This is conceived through a double specification of the unit of production and the social formation (Friedmann, 1980).

The area of agricultural land in Ukraine is 36.5 million ha. The agrarian business in economic cultivation uses $83 \%$ of the categories of farms, including: agricultural enterprises and farms - legal entities (20.7 million ha), citizens (9.3 million ha). The rest is used by the population for construction, maintenance of residential and utility buildings, as well as private households ( 5 million ha); hayfields and pastures (1.0 million ha); $2,422(6 \%)$ of farms are engaged in agrarian business own $60 \%$ of the land with an area of over 2,000 ha; 32.0 thousand farms (71\%) to the total number of agricultural formations - legal entities, which cultivate 4.6 million ha of land (23\%). Among them the most widespread size of the economy is only $20-50$ ha $(25 \%-11.8$ thousand units).

The important issue for the agrarian sector of Ukraine is the protection of commodity producers, in the process of production cycle implemented through agricultural insurance (Klapkiv, 2016). The current state of development of agricultural insurance in Ukraine is not in line with its main task of managing the risks in the agricultural sector to ensure the stability of agricultural production. About three percent of the risk is insured, while in most developed countries this figure is 90-95\% (Klapkiv, Niemczyk and Vakun, 2017).

The following methods can be used to improve the conditions for agricultural insurance and the involvement of agricultural producers in this area (Klapkiv, Klapkiv and Zarudna, 2018):

- reduction of the minimum yields in the legislation that will enable farmers to insure crops at any level of death;

- extension of the list of risks to crops by natural phenomena such as long-term showers, early occurrence of snow cover and freezing of the upper layer of soil;

- introduction of flexible agricultural insurance programs and state support for regions with high-risk agriculture;

- withdrawal of agricultural insurance from the "single subsidy".

\section{CONCLUSIONS}

It is necessary the following for the development of the agrarian sector of Ukraine, expansion of markets and successful promotion of agrarian products to the world food markets:

- focus on increasing the efficiency of production of traditional Ukrainian export products (grain crops, 
sunflower, livestock products) and increase the presence in promising sectors of the world food market in areas such as cannabis, sugar beet, flax, fruits and berries, with industrial their processing for sale abroad;

- to diversify the geographical structure of foreign trade in agricultural products (especially exports), while minimizing the dependence on individual countries on imports of certain types of agricultural products;

- to ensure, the balance of export and import of agricultural products at the state level, to achieve an increase in the surplus in foreign trade;

- gradually reorient the development of the agrarian sector's economy to increase export potential, with the condition of maintaining a balance between domestic and external demand for agricultural produce.

- to create an effective system of balance of interests of all subjects and participants of agricultural insurance with state support for the agrarian business, as well as to regulate the process of settlement of losses. In this case, the system created should ensure the effective implementation of insurance relations, including through the use of agricultural insurance instruments in the countries of the European Union.

Thus, the strengthening of globalization and integration processes actualizes the question of realization of agrarian potential. The current organizational and economic structure of the agrarian sector with its diversity of economic entities is outwardly similar to the agricultural system of the EU countries and still does not function as a coherent effective system, in the first place due to the failure to cover a significant part of the risks, although it can provide a rational growth in the production of quality food products.

\section{REFERENCES}

1. Akram-Lodhi, A.H. (2007). Land, markets and neoliberal enclosure: an agrarian political economy perspective. Third World Quarterly, 28 (8), pp. 1437-1456.

2. Bernstein, H. (1994). Agrarian classes in capitalist development. In: L. Sklair (ed.) Capitalism and Development. Routledge, New York, pp. 40-71.
3. Byres, T. (1991). The agrarian question and differing forms of capitalist agrarian transition: An essay with reference to Asia. In: J. Breman, S. Mundl (eds.) Rural transformation in Asia. Oxford University Press, New Delhi, pp. 3-76.

4. Carter, M.R., Barham, B.L. (1996). Level playing fields and laissez faire: Postliberal development strategy in inegalitarian agrarian economies. World Development, 24 (7), pp. 1133-1149.

5. Friedmann, H. (1980). Household production and the national economy: Concepts for the analysis of Agrarian formations. The Journal of Peasant Studies, 7 (2), pp. 158-184.

6. Georgescu-Roegen, N. (1960). Economic Theory and Agrarian Economics. Oxford Economic Papers. New Series, 12 (1), pp. 1-40.

7. Hymer, S., Resnick, S. (1969). A Model of an Agrarian Economy with Nonagricultural Activities. The American Economic Review, 59 (4), Part 1, pp. 493-506.

8. Jones, E.L., Woolf S.J. (eds.) (2013). Agrarian Change and Economic Development. The Historical Problems. Routledge, London.

9. Klapkiv, Y. (2016). A Strategy of institutional development in the market of insurance. Scientific bulletin of Polissia, 4 (8/1), pp. 132-136.

10. Klapkiv, Y., Klapkiv, L., Zarudna, N. (2018). Online distribution of insurance of civil liability of owners of vehicles, the experience of Poland, opportunities of Ukraine. Baltic Journal of Economic Studies, 4(1), pp. 195-201, https://www.doi.org/10.30525/22560742/2018-4-1-195-201

11. Klapkiv, Y., Niemczyk, L., Vakun, O. (2017). Financial mechanism of the insurance business. Scientific bulletin of Polissia, 4/2 (12), pp. 84-91, https://www.doi. org/10.25140/2410-9576-2017-2-4(12)-84-91

12. McMichael, P. (2012). The land grab and corporate food regime restructuring. Journal of Peasant Studies, 39 (3-4), pp. 681-701.

13. Musgrave, W.F. (1976). Problems of change in Australian agricultural economics. Australian Journal of Agricultural Economics, 20(3), pp. 133-143.

14. Putsenteilo, P. (2011). Organizational economic mechanism of sustainable development provision in beef cattle breeding. Actual Problems Of Economics, 3 (117), pp. 80-86.

15. Putsenteilo, P., Klapkiv, Y., Kostetskyi, Y. (2018). Modern challenges of agrarian business in Ukraine on the way to Europe. In: Proceedings of the 2018 International Scientific Conference 'Economic Sciences for Agribusiness and Rural Economy', 1, pp. 250-258, https://www.doi.org/10.22630/ESARE.2018.1.35 
Proceedings of the 2019 International Scientific Conference 'Economic Sciences for Agribusiness and Rural Economy' No 3, Warsaw, 5-7 June 2019, pp. 112-117

16. Razavi, S. (2009). Engendering the political economy of agrarian change. The Journal of Peasant Studies, 36 (1), pp. 197-226, https://doi.org/10.1080/03066150 902820412

17. Russi, L. (2013). Hungry capital: The financialization of food. Zero Books, Winchester.

18. Timmer, P. (1986). Getting Process Wright. The Scope and Limit's of Agricultural Policy. Cornell University Press, New York - Ithaca.
19. Tomich, T.P., Kilby, P., Johnston, B.F. (1995). Transforming Agrarian Economies: Opportunities Seized, Opportunities Missed. Cornell University Press, New York - Ithaca.

20. Wright, G., Kunreuther, H. (1975). Cotton, Corn and Risk in the Nineteenth Century. The Journal of Economic History, 35 (3), pp. 526-551, https://doi.org/10.1017/ S0022050700075628 